\title{
Acupuncture and pregnancy: oriental medicine as an ally in the treatment of low back pain
}

\author{
Acupuntura e gravidez: medicina oriental como aliada no tratamento de dor lombar
}

Eveliny Silva Martins ${ }^{1}$, Régia Christina Moura Barbosa Castro ${ }^{1}$, Lígia Maria Alves Rocha ${ }^{1}$, Ana Karina Bezerra Pinheiro $^{1}$

Objective: to identify scientific evidence in the literature on the effect of acupuncture for the relief of low back pain during pregnancy. Methods: this is an integrative literature review. The bibliographic survey included articles indexed in the portal of six databases, using controlled keywords. Results: seven articles published in English were included. The studies using acupuncture for low back pain have been successful in reducing pain, as well as increased mobility, improved sleep, a sense of well-being, increased capacity for some physical activities and improved emotional reactions of pregnant women. Conclusion: acupuncture contributed to the reduction of low back pain in the pregnant women, among other benefits, contributing to the promotion of health in a pleasurable, simple, practical, risk-free, cheap and cost-effective way.

Descriptors: Acupuncture; Pregnant Women; Nursing; Low Back Pain; Health Promotion.

Objetivo: identificar evidências científicas na literatura sobre o efeito da acupuntura para o alívio da dor lombar na gestação. Métodos: revisão integrativa de literatura. 0 levantamento bibliográfico incluiu artigos indexados no portal de seis bases de dados, utilizando palavras-chave controladas. Resultados: foram incluídos sete artigos publicados no idioma inglês. Os estudos, que utilizaram acupuntura para a lombalgia, obtiveram êxito na redução da dor, assim como aumento da mobilidade, melhoria do sono, sensação de bem-estar, aumento da capacidade para algumas atividades físicas e melhoria das reações emocionais das gestantes. Conclusão: a acupuntura contribuiu para a diminuição da lombalgia em gestantes, dentre outros benefícios, contribuindo para a promoção da saúde de forma prazerosa, simples, prática, sem riscos, barata e com bom custo benefício. Descritores: Acupuntura; Gestante; Enfermagem; Dor Lombar; Promoção da Saúde.

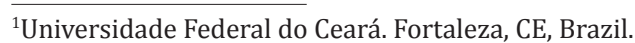




\section{Introduction}

Lumbar pain is considered the most common discomfort pain during pregnancy ${ }^{(1-4)}$ and it occurs more frequently in the third gestational trimester ${ }^{(5)}$. In recent research in Brazil, there was a high prevalence of low back pain in pregnant women, reported by $93.2 \%$ of the women ${ }^{(6)}$.

To understand the reasons causing this pain, it is emphasized that hormonal changes in pregnancy cause changes in the body of the woman, especially in the musculoskeletal system, as well as excessive growth of the uterus and breasts, imposing overload of weight on the spine and pelvis and accentuating its curvature with frontal uterine growth, modifying the position of the sacrum ${ }^{(7)}$.

Low back pain may interfere with several settings in the routine of pregnant women, such as the performance of domestic and occupational activities that, consequently, lead to impairments in the quality of life of these women.

For a better understanding of the magnitude of this problem, the study emphasizes an incidence of $77.0 \%$ of low back pain in pregnant women, revealing a considerable number of women suffering from this symptom and, worsening this condition. It is known that in the gestational period the use of medication is always a risk ${ }^{(4)}$. Such risks may be considered the teratogenic effects imposed on the fetus.

For the relief of this pain in pregnant women, there are currently some drug options, used in a systemic way, but they have limitations. Studies indicate that the treatment of low back pain in pregnancy is more complex, meticulous and delicate, given the limited therapeutic options available, precisely because of the implications for the mother and the fetus. However, an interdisciplinary and humanized care should be considered and, whenever possible, non-pharmacological therapeutic alternatives for symptom relief should be considered ${ }^{(1)}$.

A way of therapy for low back pain during pregnancy is acupuncture ${ }^{(2)}$, which seems to be effective in reducing symptoms and consequently improving the quality of life of pregnant women ${ }^{(4)}$, considerably alleviating pain compared to usual care ${ }^{(1)}$ and increasingly practiced in this group of women. Scholars reveal that pain management using acupuncture is based on results from a large number of clinical trials ${ }^{(5)}$.

The stimulation of precise anatomical points of the body (acupoints) generates the release of neurotransmitters and other substances, by the central nervous system, responsible for the analgesic effect, restoration of organic functions and maintenance of immunity ${ }^{(8)}$, providing energy balance and providing physical, mental, spiritual and emotional health.

For the World Health Organization, acupuncture is safer than many other traditional methods of treatment when performed properly by a skilled, simple, convenient professional. It has few contraindications, and it is non-toxic and exhibits minimal adverse reactions ${ }^{(9)}$. Probably because of this, it is popular in the treatment of chronic pain in several countries.

Research has shown that pregnant women have a feeling of well-being after the first sessions and claim to receive good or excellent help for their pain, since the effect of acupuncture on low back pain may be due to its analgesic and safe effect ${ }^{(5)}$ improving functional capacity and reducing the use of analgesics ${ }^{(4)}$.

Therefore, it is considered that this technique should be thoroughly studied, especially the number of sessions, viability, specific acupuncture points for low back pain in pregnant women and the nurse's performance in this practice to broaden and disseminate knowledge and the benefits of this technique. Thus, it contributes to the promotion of health and the advancement of nursing science through the work of the nurse, as the therapist who uses natural techniques, based on energy balance, providing relief of pain mainly to the neediest people, the pregnant women.

From this perspective, the objective of this study was to identify scientific evidence in the literature on the effect of acupuncture for the relief of low back pain during pregnancy. 


\section{Methods}

This research was based on the integrative review, since this strategy synthesizes results of previous research showing conclusions of the literature on a specific phenomenon, allowing, with its summarized and separated data, the achievement of general results on the research problem, following a systematic process and summarized literature ${ }^{(10)}$.

The construction of this review took place in six distinct stages: 1 . The identification of the theme and selection of the hypothesis or research question; 2 . The establishment of criteria for inclusion and exclusion of studies/sampling or search in the literature; 3. The definition of the information to be extracted from the selected studies/categorization of the studies; 4. The evaluation of the studies included in the review; 5. The interpretation of results; 6 . The presentation of the review/synthesis of knowledge ${ }^{(11)}$.

The literature review included articles indexed in the Scientific Electronic Library (SCIELO), SCOPUS, Public Medline (PUBMED), Latin American Literature in Health Sciences (LILACS), Medical Literature Analysis and Retrieval System Online (MEDLINE); Cumulative Index to Nursing \& Allied Health Literature (CINAHAL).

This survey was conducted in January 2016 and it was guided by the following question: what are the effects of acupuncture in the treatment of low back pain in pregnant women? The articles were considered eligible if they were published in journals indexed in the mentioned basis, through the use of the controlled descriptors: Acupuntura; Gestantes; Dor lombar and Acupuncture; Pregnant Women; Low back pain.

The inclusion criteria of the definite articles were: to be a complete research article, to be available electronically, to be published in Portuguese, English or Spanish, and to show the use of acupuncture in low back pain in pregnant women, without restriction of publication date. The exclusion criteria adopted were: not the adequacy of the objectives of the study; Informal case reports, book chapters, reflective articles, dissertations, theses, reports, editorials of non-scien- tific journals and studies with the inability to access.

After the inclusion of the three descriptors and using the Boolean operator AND, a total of 378 articles were found in the databases, except for LILACS and SCIELO. Of these articles, there were 352 articles did not address the desired theme, three were not available, 12 were repeated and four were included in the inclusion criteria. As a result of this analysis, the final sample comprised seven articles.

A data collection instrument was used for the analysis of the articles, including information about the database, year of publication, type of study, author's training, country, language, general objective, sample of participants, gestational age, as well as the instruments used, acupuncture points, time and main results found. The analysis of the data occurred through in-depth reading of the content.

\section{Results}

For a better understanding of the included studies, Figure 1 shows the details of the studies. It was observed that the articles were produced from 2000 and the last publications were in 2010. The articles are presented according to the methodological characteristics and origin of the publications.

Regarding the type of the study, most of the research was categorized as quantitative studies, except for one (02) that evaluates both quantitative and qualitative aspects. Of the seven studies included, four were prospective, two clinical trials and one cross-sectional.

When analyzing the professional graduation of the authors, it was observed that most of the articles were developed by medical professionals ${ }^{(6)}$, only one of the articles was authored by a nurse. It is observed that one article was produced in Brazil, two in the United States and four in Sweden. It should be noted that all research was published in English.

Figure 2 shows the objectives, sample of participants and if there was the use of instruments that evaluate the pain of the included articles. 


\begin{tabular}{|l|l|l|l|c|c|c|}
\hline Study & Database & Year & Study design & $\begin{array}{c}\text { Author's } \\
\text { graduation }\end{array}$ & Country & Language \\
\hline $\begin{array}{l}\text { 1. Acupuncture for low back pain in pregnancy - a } \\
\text { prospective, quasi- randomized, controlled study }\end{array}$ & Medline & 2010 & $\begin{array}{c}\text { Prospective, } \\
\text { controlled }\end{array}$ & Doctor & Brazil & English \\
\hline $\begin{array}{l}\text { 2. Acupuncture treatment of pregnant women with low } \\
\text { back and pelvic pain an intervention study }\end{array}$ & Medline & 2010 & $\begin{array}{c}\text { Part clinical trial } \\
\text { and qualitative part }\end{array}$ & Nurse & Sweden & English \\
\hline $\begin{array}{l}\text { 3. Auricular acupuncture as a treatment for pregnant } \\
\text { women who have low back and posterior pelvic pain: a } \\
\text { pilot study }\end{array}$ & Medline & 2009 & $\begin{array}{c}\text { Randomized } \\
\text { clinical trial, } \\
\text { controlled }\end{array}$ & Doctor & U.S.A. & English \\
\hline $\begin{array}{l}\text { 4. Decrease of pregnant women's pelvic pain after } \\
\text { acupuncture: a randomized controlled single-blind study }\end{array}$ & Scopus & 2006 & $\begin{array}{c}\text { Prospective and } \\
\text { randomized } \\
\text { controlled }\end{array}$ & Doctor & Sweden & English \\
\hline $\begin{array}{l}\text { 5. Complementary and alternative medicine for low- } \\
\text { back pain in pregnancy: a cross-sectional survey }\end{array}$ & Medline & 2005 & Cross-sectional & Doctor & U.S.A. & English \\
\hline $\begin{array}{l}\text { 6. Acupuncture relieves pelvic and low-back pain in late } \\
\text { pregnancy }\end{array}$ & Medline & 2004 & $\begin{array}{l}\text { Prospective, } \\
\text { randomized }\end{array}$ & Doctor & Sweden & English \\
\hline $\begin{array}{l}\text { 7. A prospective randomized study comparing } \\
\text { acupuncture with physiotherapy for low-back and pelvic } \\
\text { pain in pregnancy }\end{array}$ & Medline & 2000 & $\begin{array}{l}\text { Prospective, } \\
\text { randomized }\end{array}$ & Doctor & Sweden & English \\
\hline
\end{tabular}

Figure 1 - Description of the studies included in the integrative review according to the database, year of publication, the design, author's graduation, country, and language

\begin{tabular}{|c|c|c|c|c|}
\hline Study & Objectives of the study & $\begin{array}{l}\text { no of preg- } \\
\text { nant women }\end{array}$ & $\begin{array}{c}\text { Gestatio- } \\
\text { nal age }\end{array}$ & Instruments \\
\hline 1 & $\begin{array}{l}\text { To investigate the effects of acupuncture on low back and pelvic } \\
\text { pain during pregnancy under real conditions compared to } \\
\text { patients undergoing conventional treatment }\end{array}$ & 79 & $<32$ s & Numerical Rating Scale (NRS) \\
\hline 2 & $\begin{array}{l}\text { Describe the experience of women who use acupuncture } \\
\text { treatment to relieve lower back and pelvic pain at week } 20 \text { and } \\
26 \text { of pregnancy. }\end{array}$ & 40 & $\begin{array}{l}\text { Average of } \\
26 \mathrm{~s}\end{array}$ & $\begin{array}{c}\text { Visual Analog Scale (EVA); Pain- } \\
\text { O-Meter (POM); Short FormMcGill } \\
\text { Questionnaire (SF-MPQ); } \\
\text { Short Form-36 Health Survey } \\
\text { Questionnaire (SF-36) }\end{array}$ \\
\hline 3 & $\begin{array}{l}\text { Check if a week of continuous auricular acupuncture could } \\
\text { reduce lower back and pelvic pain associated with pregnancy. }\end{array}$ & 152 & $\begin{array}{l}20 \text { and } \\
26 s\end{array}$ & $\begin{array}{l}\text { Visual Analog Scale (EVA) and } \\
\text { Disability Rating Index (DRI) }\end{array}$ \\
\hline 4 & $\begin{array}{l}\text { To evaluate the effects of two different forms of acupuncture } \\
\text { stimulation (superficial and deep) on the intensity of lumbar } \\
\text { and pelvic pain in late pregnancy and some emotional } \\
\text { symptoms due to the pain condition. }\end{array}$ & 70 & 18 to $35 \mathrm{~s}$ & $\begin{array}{l}\text { Visual Analogue Scale (EVA) and } \\
\text { Nottingham Health Profile (NHP) }\end{array}$ \\
\hline 5 & $\begin{array}{l}\text { To identify common treatments used for low back pain during } \\
\text { pregnancy. }\end{array}$ & 950 & 15 to $30 \mathrm{~s}$ & - \\
\hline 6 & $\begin{array}{l}\text { To evaluate the analgesic effect and possible adverse effect } \\
\text { of acupuncture for pelvic and lumbar pain during the last } \\
\text { trimester of pregnancy. }\end{array}$ & 72 & 25 to $38 \mathrm{~s}$ & Visual Analog Scale (EVA) \\
\hline 7 & $\begin{array}{l}\text { To describe the effects of acupuncture in the treatment of low } \\
\text { back and pelvic pain during pregnancy and to compare it with } \\
\text { physical therapy. }\end{array}$ & 60 & 24 to $37 \mathrm{~s}$ & $\begin{array}{l}\text { Visual Analog Scale (EVA) and } \\
\text { Disability-Rating Index (DRI) }\end{array}$ \\
\hline
\end{tabular}

Figure 2 - Distribution of studies included in the review according to their objectives, sample of participants, instruments assessing pain and gestational age 
From the analysis of the objectives of the included studies, it was observed that more than half of them $(4,6,7,1)$ had the purpose of investigating the effects of systemic acupuncture on low back pain in pregnant women, an article (3) evaluated acupuncture, other (2) also aimed to listen to the pregnant women who used acupuncture, and the last one (7) identified alternative complementary medicine methods for pain relief, among them acupuncture.

It was observed that all studies were performed with a minimum of 40 participants and a maximum of 950. Regarding the gestational age of the participants of the articles found, it was observed that all were performed in women with a minimum of 15 and a maximum of 38. inferring that low back pain starts to affect the pregnant woman after the second trimester and lasts until the third gestational trimester.

Analysis of the instruments reveals that most of the articles $(4,2,3,6,7)$ used the visual analog pain scale to measure the evolution/worsening of lumbar pain before or after acupuncture treatment.

Figure 3 shows the data regarding the acupuncture points used, the time the needles remained and the main results in the low back pain of pregnant women.
From the analysis of the included articles, almost all the studies found $(4,3,6,7,1)$ were concerned with describing the acupuncture points used for the treatment of low back pain, and the other studies did not explain this information in the methods, hindering to fully understand how they achieved the objective results.

Regarding to the time the needles remained during the acupuncture session, three studies $(4,2,7)$ used them for a period of 30 minutes, one study (6) for 25 minutes, one study (6) manipulated them until the arrival of the Dechi, repeating after 30-60s, removing them soon after, and the other study (3) left the needles for a week, because it was an auricular-acupuncture. The number of sessions for the treatment of low back pain was eight $(2,6)$, ten $(4,7)$ and twelve $(4)$ times. Two articles did not include this information and one study performed a single treatment for a week.

Thus, it was observed that all articles using acupuncture therapy for low back pain have been successful in reducing pain and its intensity, as well as increased mobility, improved sleep, well-being, increased capacity to some physical activities and improvement of emotional reactions.

\begin{tabular}{|c|c|c|c|}
\hline Study & Points & Time & Results \\
\hline 1 & $\begin{array}{l}\text { R3, ID3, B62, B40, } \\
\text { TE5, VB30, VB41 }\end{array}$ & $\begin{array}{l}\text { Eight to } 12 \text { sessions - } 25 \\
\text { minutes in each }\end{array}$ & $\begin{array}{l}\text { Relief of low back pain, increased capacity for certain daily activities and } \\
\text { improved quality of life for pregnant women }\end{array}$ \\
\hline 2 & - & $\begin{array}{l}\text { Eight sessions - } 30 \text { minutes } \\
\text { in each }\end{array}$ & $\begin{array}{l}\text { Most women }(80.0 \%) \text { had a significant reduction of pain, better mobility and } \\
\text { sleep after acupuncture treatment. Significant improvement in general health } \\
\text { and social function }\end{array}$ \\
\hline 3 & $\begin{array}{l}\text { Headphones: } \\
\text { Kidney, Analgesia, } \\
\text { and Shenmen }\end{array}$ & $\begin{array}{l}\text { One week - semi- } \\
\text { permanent needles }\end{array}$ & $\begin{array}{l}\text { The pregnant women reported significantly lower pain intensity when } \\
\text { compared with the other groups }\end{array}$ \\
\hline 4 & $\begin{array}{l}\text { B27, B28, B29, B31, } \\
\text { B32, B54, R11, VC3, } \\
\text { BP6, F2, IG4 }\end{array}$ & $\begin{array}{l}10 \text { sessions - } 30 \text { minutes } \\
\text { each }\end{array}$ & $\begin{array}{l}\text { Change in pain intensity during daily activities: Most women report lower } \\
\text { levels of pain, changes in pain intensity, and emotional reactions }\end{array}$ \\
\hline 5 & - & - & $\begin{array}{l}53.0 \% \text { reported using various alternative therapies before pregnancy, including } \\
\text { acupuncture. } 60.0 \% \text { of the pregnant women continued to use complementary } \\
\text { and alternative medicine during pregnancy and } 61.7 \% \text { would accept this } \\
\text { treatment for low back pain during pregnancy }\end{array}$ \\
\hline 6 & $\begin{array}{l}\text { F3, VG20, B60, ID3, } \\
\text { B22, B26 and local } \\
\text { pain points }\end{array}$ & $\begin{array}{l}\text { The manipulation of the } \\
\text { needle was stopped with } \\
\text { the Dechi, repeated after } \\
30-60 \text { s and removed }\end{array}$ & $\begin{array}{l}\text { The intensity of low back pain decreased in } 60.0 \% \text { of pregnant women in the } \\
\text { third trimester and pain associated with various physical activities decreased } \\
\text { by } 43.0 \%\end{array}$ \\
\hline 7 & $\begin{array}{l}\text { B26, B30, B60, VC2, } \\
\text { local pain points } \\
\text { and headphones }\end{array}$ & $\begin{array}{l}10 \text { sessions - } 30 \text { minutes } \\
\text { each }\end{array}$ & $\begin{array}{l}\text { Visual and analog scale values were significantly reduced compared to pre- } \\
\text { treatment values. There was relief from pain and disability, feeling tired or } \\
\text { drowsy, as well as a sense of well-being }\end{array}$ \\
\hline
\end{tabular}

Figure 3 - Distribution of studies included in the integrative review on acupuncture points, time and main results in low back pain in pregnant women 


\section{Discussion}

This study shows the scarce quantity of published articles referring to the subject in question as a limitation, due to its specificity, as well as the outdated, since the last year of publication was almost six years ago. It is noteworthy that the search was done in six databases with significant collections of scientific research. Therefore, it is suggested to carry out new research aimed at the pregnant women.

It is important to elucidate also that there are several publications about the effects/benefits of acupuncture therapy in different populations. However, the number of research developed with the pregnant women is small, especially those with low back pain. It is emphasized that low back pain is one of the main causes of pain in pregnant women, deserving greater emphasis on scientific and technological research.

Few studies on acupuncture treatment in pregnant women with low back pain and pelvic pain are published nationally or internationally ${ }^{(2)}$.

Thus, it is important to invest in research involving the treatment of pregnant women suffering from low back pain, since many of them consider pain as normal or acceptable, also being informed about limited therapeutic resources. Thus, the intention is to alert and inform health professionals that there are other ways, such as acupuncture, to treat this pain and not having risks to mother and fetus, leaving aside the erroneous idea that it is normal for pregnant women to feel low back pain.

Because most of the articles found have used the visual analog pain scale, it is inferred to be a reliable and widely used instrument for this purpose, probably because of its ease of applicability, requiring little time to fill.

From the acupuncture points used, they all manipulated the meridian of the bladder (B). When stimulated, it causes an analgesic effect on low back pain, among other benefits ${ }^{(12)}$. In traditional Chinese acupuncture, one of the locations of the body in which this meridian passes, it is through the dorsal region and down to the lumbar. Excess energy in the bladder meridian can cause pain in the spine and insufficiency can lead to intercostal pain radiating to the lumbar region, among other effects ${ }^{(12)}$.

Other common meridians were found in the articles, such as the kidney (K), liver (L), small intestine (SI) and vessel conception (VC). Two articles also used auricular acupuncture points and two used symptomatic points of pain, called ashi points, combined or alone, to treat low back pain in pregnant women.

Different to what some authors report, there are no contraindicated points in pregnancy, but rather, the association of points that tone or disperse energies and consequently lead to premature labor. Thus, all points can be indicated, especially when there are disturbances in pregnancy. It is worth mentioning that some authors have associated acupuncture points that induce or favor delivery, such as large intestine (LI) 4 - pancreas spleen (PS) 6 - VC3 and L3 - B60. This fact is treated with imprudence in the therapeutic action with pregnant women ${ }^{(13)}$.

The other points stimulated during the treatment were considered positive since they provide specific effects that can reduce low back pain, tone the kidney, calm the mind, benefit the tendons and joints and move the energy/blood, improving maternal health. In short, these isolated points can be used with care, but the main one is to be careful not to associate these points in the treatment of pregnant women.

The intensity of low back pain in pregnant women in the third trimester decreased in $60.0 \%$ of participants in the systemic acupuncture group and in $14.0 \%$ in the control group $(\mathrm{p}<0.010)^{(14)}$.

It is known that low back pain often affects pregnant women. However, acupuncture is useful for women who have recurrent or excessive periods of pain ${ }^{(2)}$. It was found that performing auricular-therapy for one week in pregnant women favored a significant reduction of low back pain in $80.0 \%$ of the participants in the acupuncture group when compared to $56.0 \%$ in the simulated acupuncture group and $36.0 \%$ of the control group ${ }^{(15)}$. 
The acupuncture technique reveals positive therapeutic results contributing to reduce or alleviate the suffering caused by low back pain and, consequently, benefits the daily routine, the ability to perform tasks, and the general health of pregnant women.

The main activities that triggered or accentuated low back pain in pregnant women were: walking or sitting in $57.1 \%$ of the cases and $42.8 \%$ reported that at bedtime the pain decreased. The frequency of pain was reported by $52.3 \%$ of the volunteers as being of constant intensity, appearing more commonly in the morning with $19.1 \%{ }^{(6)}$.

According to research results, some participants in the $20^{\text {th }}$ and $26^{\text {th }}$ weeks of pregnancy (groups 1 and 2, respectively) reported that they were able to work during pregnancy. However, three women in group 1 reported that they could not be reduced low back pain and improved sleep quality without acupuncture treatment ${ }^{(2)}$.

The treatment for low back pain in pregnant women did not present serious adverse events related to acupuncture ${ }^{(4,5,14-15)}$. However, symptoms such as local pain, heat, local bruising and weakness, reported by $38.0 \%$ of the patients who received acupuncture may occur ${ }^{(14)}$.

To corroborate the above data, a systematic review of 105 articles on the safety of acupuncture during pregnancy found that most of the adverse events are mild and transient, with very few being severe. Needle insertion was the most common mild adverse event, followed by bleeding. The rare serious adverse events found were all assessed as unlikely to have been caused by acupuncture treatment ${ }^{(16)}$.

It was found that acupuncture therapy caused faster relief and had a better effect on the restriction of function in pregnant women with low back pain than physical therapy ${ }^{(5)}$. It is also worth noting that concerns about pharmacological treatment during pregnancy have helped to increase the use of acupuncture $^{(16)}$.

It is worth mentioning that no patient in the acupuncture group used analgesic drugs $(\mathrm{p}<0.050)^{(14)}$, since, if used properly, acupuncture therapy may reduce the need for medications ${ }^{(17)}$.

These results contribute to raise awareness about the importance and need of professionals, especially nurses, who work in prenatal care, to get to know and to be informed about acupuncture and other alternative therapies in this population, so they can increase the options of analgesia for back pain, among others, reducing the use of medicines, promoting the health and the consequent comfort of these women.

It is considered that this technique should be more studied in this people because it can reduce pain, promote health in a pleasurable, simple, convenient, practical, risk-free, relatively inexpensive and cost-effective way.

\section{Conclusion}

The effects of this therapy decreased pain intensity and benefited emotional reactions, mobility, sleep, disability, fatigue, as well as providing a sense of well-being and improving the quality of life of pregnant women. There is a variation in the methodology regarding acupuncture points and session time for the treatment of low back pain in pregnant women. However, it was found that many sessions were necessary to alleviate low back pain and a very small number of articles were performed by professional nurses.

\section{Collaborations}

Martins ES contributed in the design and project or analysis and interpretation of data, article writing, critical review of relevant intellectual content. Rocha LMA contributed to the design and project, analysis and interpretation of the data. Pinheiro AKB and Castro RCMB contributed to the writing of the article or critical review of the relevant intellectual content and final approval of the version to be published. 


\section{References}

1. Gallo-Padilla D, Gallo-Padilla C, Gallo-Vallejo FJ, Gallo-Vallejo JL. Lumbalgia durante el embarazo. Abordaje multidisciplinar. Semergen. 2016; 42(6):59-64. doi: http://dx.doi.org/ 10.1016/j. semerg.2015.06.005

2. Ekdahl L, Petersson K. Acupuncture treatment of pregnant women with low back and pelvic pain an intervention study. Scand J Caring Sci. 2010; 24(1):175-82. doi: http://dx.doi.org/10.1111/ j.1471-6712.2009.00704.x

3. Katonis P, Kampouroglou A, Aggelopoulos A, Kakavelakis K, Lykoudis S, Makrigiannakis A, et al. Pregnancy-related low back pain. Hippokratia [Internet]. 2011 [cited 2017 Mar 30]; 15(3):20510. Available from: https://www.ncbi.nlm.nih. gov/pmc/articles/PMC3306025/

4. Silva ALP. O tratamento da ansiedade por intermédio da acupuntura: um estudo de caso. Psicol Cienc Prof. 2010; 30(1):200-11. doi: http://dx. doi.org/10.1590/S1414-98932010000100015

5. Wedenberg K, Moen B, Norling A. A prospective randomized study comparing acupuncture with physiotherapy for low-back and pelvic pain in pregnancy. Acta Obstet Gynecol Scand. 2000; 79(5):331-5. doi: http://dx.doi.org/10.1034/ j.1600-0412.2000.079005331.x

6. Gomes MRA, Araújo RC, Lima AS, Pitangui ACR. Gestational low back pain: prevalence and clinical presentations in a group of pregnant women. Rev Dor. 2013;14(2):114-17. doi: http://dx.doi. org/10.1590/S1806-00132013000200008

7. Martins RF, Silva JLP. Prevalência de dores nas costas na gestação. Rev Assoc Med Bras [Internet]. 2005 [citado 2017 mar. 30]; 51(3):144-7. Disponível em: http://www.scielo.br/pdf/ramb/ v51n3/a14v51n3.pdf

8. Ministério da Saúde (BR). Portaria no 971, de 03 de maio de 2006. Aprova a Política Nacional de Práticas Integrativas e Complementares (PNPIC) no Sistema Único de Saúde. Brasília: Ministério da Saúde; 2006.
9. World Health Organization. Acupuncture: review and analysis of reports on controlled clinical trials. [Internet]. 2002 [cited 2017 Mar. 30]. Available from:http://www.iama.edu/OtherArticles / acupuncture_WHO_full_report.pdf

10. Crossetti MGO. Revisão integrativa de pesquisa na enfermagem: o rigor cientifico que lhe é exigido [Editorial]. Rev Gaúcha Enferm. 2012; 33(2):8-9.

11. Mendes KDS, Silveira RCCP, Galvão CM. Revisão integrativa: método de pesquisa para a incorporação de evidências na saúde e na enfermagem. Texto Contexto Enferm. 2008; 17(4):75864. doi: http://dx.doi.org/10.1590/S010407072008000400018

12. Dulcetti Júnior O. Pequeno tratado da acupuntura tradicional chinesa. São Paulo: Andrei; 2001.

13. Auteroche B, Navailh P. Acupuntura em ginecologia e obstetrícia. São Paulo: Andrei; 1985.

14. Kvorning N, Holmberg C, Grennert L, Aberg A, Akeson J. Acupuncture relieves pelvic and lowback pain in late pregnancy. Acta Obstet Gynecol Scand. 2004; 83(3):246-50. doi: http://dx.doi. org/10.1111/j.0001-6349.2004.0215.x

15. Wang SM, Dezinno P, Lin EC, Lin H, Yue JJ, Berman MR, et al. Auricular acupuncture as a treatment for pregnant women who have low back and posterior pelvic pain: a pilot study. Am J Obstet Gynecol. 2009; 201(3):e1-9. doi: http://dx.doi. org/10.1016/j.ajog.2009.04.028

16. Park J, Sohn Y, White AR, Lee H. The safety of acupuncture during pregnancy: a systematic review. Acupunct Med. 2014; 32(3):257-66. doi: http:// dx.doi.org/10.1136/acupmed-2013-010480

17. Silva JBG da, Nakamura UM, Cordeiro JA, Júnior LK. Acupuncture for low back pain in pregnancy - a prospective, quasi- randomised, controlled study. Acupunct Med. 2010; 22(2):60-67. doi: http:// dx.doi.org/10.1136/aim.22.2.60 